Journal of the Geological Society

\title{
The significance of hiatal surfaces in coal seams
}

R.M. Jerrett, R.C. Davies, D.M. Hodgson, et al.

Journal of the Geological Society 2011; v. 168; p. 629-632

doi: 10.1144/0016-76492010-178

Email alerting click here to receive free e-mail alerts when new articles cite this article service

Permission

click here to seek permission to re-use all or part of this article request

Subscribe click here to subscribe to Journal of the Geological Society or the Lyell Collection

\section{Notes}

Downloaded by on April 27, 2011

(C) The Geological Society of London

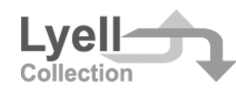




\section{S P E C I A L}

\section{The significance of hiatal surfaces in coal seams}

\author{
R. M. JERRETT ${ }^{1,2 *}, \mathrm{R} \cdot \mathrm{C} \cdot \mathrm{DAVIES}^{3}$, \\ D. M. HODGSON ${ }^{1}$, S. S. FLINT ${ }^{1}$ \\ \& R. C. CHIVERRELL ${ }^{1}$ \\ ${ }^{1}$ School of Environmental Sciences, University of Liverpool, \\ 4 Brownlow Street, Liverpool L69 3GP, UK \\ ${ }^{2}$ Present address: School of Geography, Earth and \\ Environmental Sciences, University of Plymouth, Drake \\ Circus, Plymouth PL4 8AA, UK \\ ${ }^{3}$ E.ON Ruhrgas Norge AS, Løkkeveien 107, 4007 Stavanger, \\ Norway \\ *Corresponding author (e-mail: \\ rhodri.jerrett@plymouth.ac.uk)
}

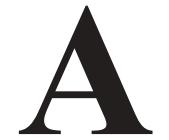

widespread misconception is that coals correspond to single palaeo-peat bodies, which represent continuous and time-invariant records of peat accumulation. Evidence for the occurrence of intra-seam hiatal surfaces within datasets from bituminous coals, lignites and modern peats suggests that existing depositional models for peat and coal require modification. Recognition that coals may represent a succession of stacked mires separated by hiatal surfaces has implications for palaeoenvironmental and sequence stratigraphic studies that assume a continuous record of peat accumulation, as well as for the prediction of whole-seam composition and thickness trends.

In peat-forming environments (mires), a continuously rising mire water table (base level) relative to the sediment surface generates the accommodation required for peat to accumulate (Ingram 1978; Clymo 1984; Diessel 1992). The rate at which accommodation is generated is a function of the interplay between the height of the mire water table (controlled by low rates of hydraulic conductivity in the peat, climatic wetness and/or eustatic sea level) and the sediment surface (controlled by tectonics and sediment compaction). Several published conceptual models attempt to explain the response of peat-forming depositional systems to changes in the rate of accommodation creation (e.g. Bohacs \& Suter 1997; Wadsworth et al. 2002). These models are based on the principle that for peat to accumulate and be preserved, the long-term accommodation rate (AR) must balance the peat production rate (PPR) (Fig. 1). If the long-term AR outpaces the PPR, the mire will be drowned and buried by marine or lacustrine clastic sediments. Conversely, if the long-term AR falls below the PPR, the peat will be exposed, oxidized, eroded and replaced by terrigenous clastic sediments.

Clastic splits within coals are clear indicators of cessation and re-establishment of peat accumulation (Staub 1991; Shearer et al. 1994; Greb et al. 2002; Davies et al. 2006). Numerous studies, however, show evidence for periods of hiatus across surfaces within coal and peat successions without the deposition of clastic sediments (e.g. Watts 1971; Shearer et al. 1994; Holdgate et al. 1995; Page et al. 2004), indicating that disequilibrium between the accommodation rate and the peat production rate may result in the development of hiatal surfaces. The aims of this paper are to (1) examine the lines of evidence for hiatal surfaces within coals and peat, and (2) discuss the implications of hiatuses and variable rates of peat accumulation for depositional models and studies of peat and coal-bearing strata.

The evidence for hiatal surfaces within coals and peat falls into four groups, as follows.

Petrographic trends. Using a volcanic ash layer interbedded within the Upper Carboniferous Fire Clay Coal (Kentucky, USA) as a datum, it is possible to correlate compositional changes stratigraphically through the coal over distances of more than 100 km (Greb et al. 1999; Jerrett et al. 2011) (Fig. 2a). Detailed petrographic analysis of closely spaced samples from multiple vertical sections through the coal demonstrates that it contains at least six stacked palaeomires, each with different overall compositions and areal distributions (Jerrett et al. 2011). Each palaeomire succession is $0.2-0.3 \mathrm{~m}$ thick, and characterized by an upward decrease in humified plant material (vitrinite) and an upward increase in oxidized plant material (inertinite) and plant components resistant to degradation such as liptinite and inherent mineral matter.

The bounding surfaces between the stacked mires are characterized by an abrupt shift from a degraded maceral assemblage of inertinite, liptinite and detrital minerals at the top of the underlying palaeomire, to laminated coal dominated by humified plant material (vitrinite). These bounding surfaces are readily identifiable in petrographic profiles through the Fire Clay Coal and are also clearly visible on polished block samples (Fig. 3a). The degraded maceral assemblage below the bounding surface is interpreted as a residual layer that formed following oxidative degradation of peat owing to the water table falling below the peat surface, whereas the overlying vitrinite-rich, laminated coal represents re-initiation of peat accumulation in a new mire. The oxidized nature of the coal underlying the bounding surfaces together with the abrupt coal facies shift that occurs above them and the different overall composition and areal distribution of each successive palaeomire suggests that the bounding surfaces represent periods of regional hiatus in peat accumulation.

Stratigraphic relationships. Abrupt petrographic discontinuities similar to those described in the Fire Clay Coal have also been recognized in the Sunnyside Coal of the Upper Cretaceous Blackhawk Formation in eastern Utah, USA (Fig. 3b; Davies et al. 2006). Correlation of petrographic trends combined with the stratigraphic relationship between the Sunnyside Coal and coeval shallow marine and valley-fill sediments suggests that the coal spans the formation of two high-frequency sequence boundaries (Fig. 2b). On this basis, the petrographic discontinuity surfaces within the coal represent the organic equivalent of sequence boundaries (Davies et al., 2006). The duration of the sequences within the Blackhawk Formation is estimated to be $100-400 \mathrm{ka}$ (Taylor \& Lovell 1995), whereas the maximum thickness of coal between the two bounding surfaces is c. $2 \mathrm{~m}$ (Davies et al., 2006). Assuming peat-to-coal compaction ratios of 10:1 (Ryer \& Langer 1980) gives a peat accumulation rate of between 0.05 and $0.2 \mathrm{~mm} \mathrm{a}^{-1}$, which is significantly less than accumulation rates of Holocene peats at similar latitudes (Diessel et al. 2000). It is therefore likely that a significant hiatus in peat accumulation occurred during base-level fall associated with each of the sequence boundaries. Diessel (1998) and Lindsay \& Herbert (2002) also correlated degraded and mineral-enriched horizons 


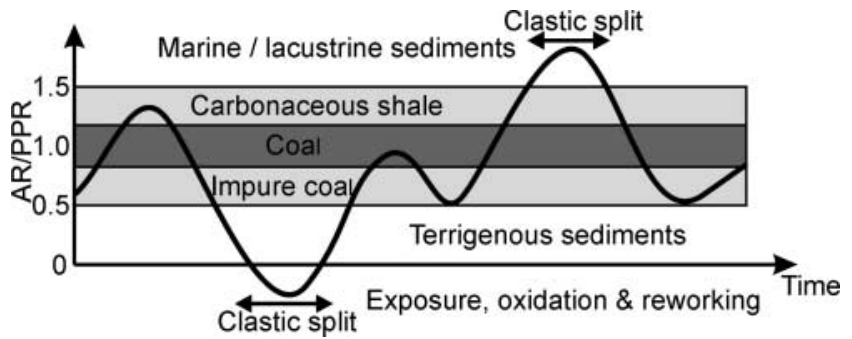

Fig. 1. Model showing the relationship between accommodation rate (AR), peat production rate (PPR) and the formation of clastic splits and coal. Modified from Wadsworth et al. (2002).
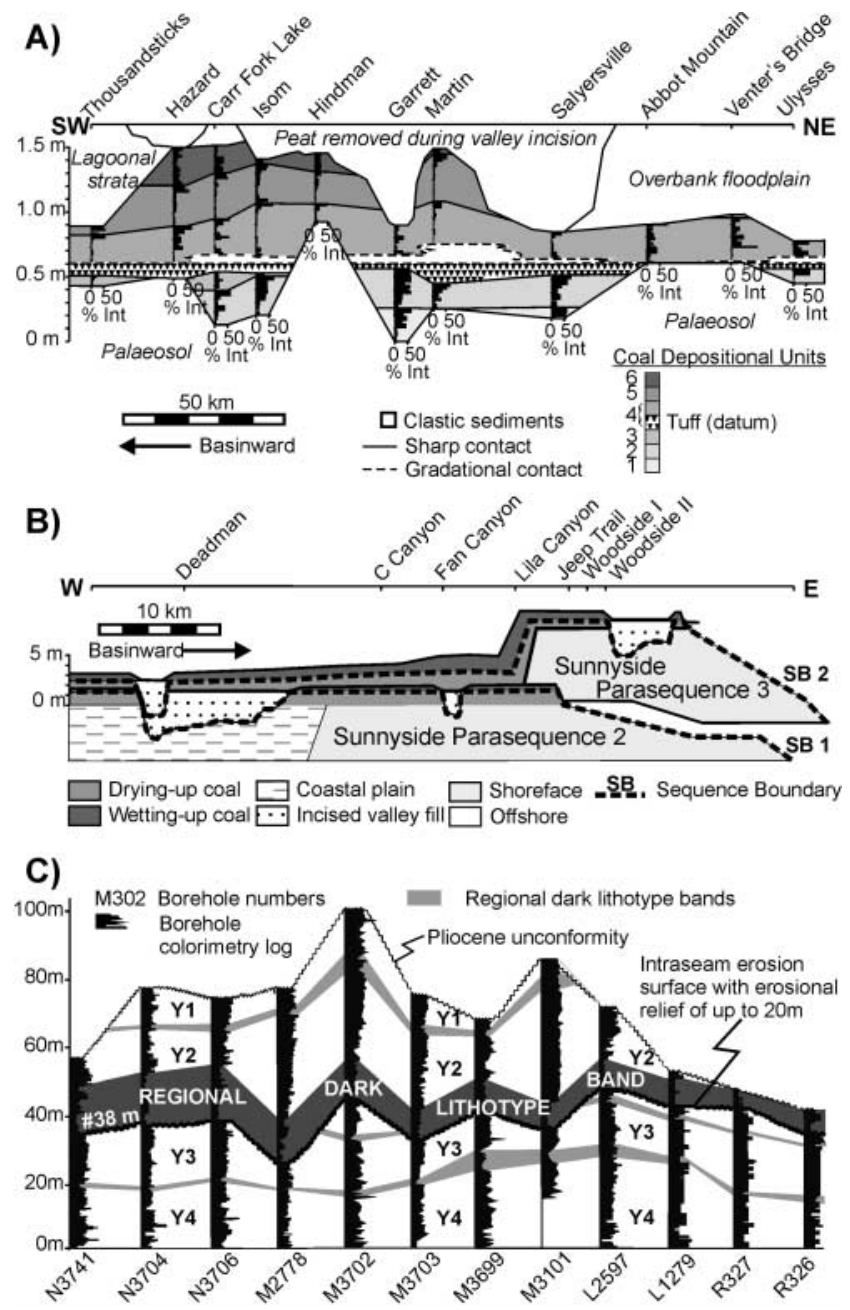

Fig. 2. (a) Schematic cross-section and inertinite content (Int) of the Upper Carboniferous Fire Clay Coal (Kentucky). The increased inertinite content at the top of each depositional unit represents a phase of increased oxidation and degradation of peat. The different overall composition and areal distribution of each unit indicates hiatus at the unit bounding surfaces. (b) Schematic cross-section through the Upper Cretaceous Sunnyside Coal (Utah) showing the relationship between the coal and time-equivalent clastic strata. Drying-up successions culminate in a surface that correlates laterally to the bases of valleys incised during base-level fall. Modified from Davies et al. (2006). (c) Schematic crosssection and colorimetry logs showing internal truncation of regionally extensive dark lithotype bands in the Tertiary Yallourn brown coal (Victoria, Australia). Modified from Holdgate et al. (2007). within Permian coals in Australia to the bases of valleys incised during sea-level fall.

Truncation surfaces in lignites. Holdgate et al. (1995, 2007) described a prominent series of 10-20 m thick lightening-upward cycles in five c. $100 \mathrm{~m}$ thick Tertiary lignites of the Gippsland Basin in Victoria, Australia. These cycles are characterized by a basal erosion surface overlain by dark, laminated coal containing abundant well-preserved plant tissue, marine-derived sediment and high organic sulphur grading upwards to pale coal abundant in degraded plant material and liptinites. Evidence for substantial hiatus at the base of cycles comes from erosional relief of up to $20 \mathrm{~m}$ (Fig. 2c), and the termination of underlying faults at the cycle boundaries. The age ranges of the coals are constrained by pollen biostratigraphy (Holdgate et al. 2009). Where the Upper P. tuberculatus Morwell 1A and Middle P. tuberculatus Morwell 1B coals merge to give $180 \mathrm{~m}$ of continuous lignite, the bounding surface between the two coals represents a hiatus of at least $300 \mathrm{ka}$.

Accumulation rates of mid- to low-latitude Late Quaternary organic sediments. Long peat records approaching the $c .50 \mathrm{ka}$ limit of ${ }^{14} \mathrm{C}$ dating techniques are generally confined to the midto low latitudes, which remained unglaciated during the Pleistocene. Based on ${ }^{14} \mathrm{C}$ age profiles, a significant reduction or hiatus in peat accumulation and lacustrine organic sedimentation is recognized across the Last Glacial Maximum (LGM) in the eastern USA (Webb \& Webb 1988; Booth et al. 1999), Australia (Kershaw 1995) and SE Asia (Anshari et al. 2001; Page et al. 2004). In Kalimantan, Indonesia, the hiatus between c. 20 and 10 ka BP represents more than a third of the time since peat accumulation initiated, and in many of the records, hiatuses in accumulation are marked by an abrupt change in the texture, mineral and/or floral composition of the peat (Booth et al. 1999; Anshari et al. 2001). The coincidence of these hiatuses with the LGM suggests that peat accumulation was terminated by watertable drawdown associated with lowered sea level (Watts 1971; Booth et al. 1999) and/or increased global aridity (Webb \& Webb 1988), which also resulted in a widespread hiatus in the lacustrine sediment record (e.g. Watts 1971; Ledru et al. 1998).

Discussion. In the coal case studies presented above, the oxidized nature of the coal underlying the hiatal surfaces, the correlation of the surfaces to periods of lowered sea level or increased aridity and/or the erosive nature of the surfaces suggest that peat accumulation ceased in response to water-table (baselevel) fall. There is, however, little evidence for terrigenous clastic sedimentation replacing peat accumulation at low accommodation rates, as suggested by the models of Bohacs \& Suter (1997) and Wadsworth et al. (2002). The existing models indicate that peat accumulation ceases at AR/PPR $<0.5$ (Fig. 1), but do not explain a mechanism for this phenomenon. Additionally, the existing models assume that there is always a sufficient supply of clastic sediment available to take up any excess space not filled by peat accumulation. Figure $4 \mathrm{a}$ shows a proposed modification of the model to account for these issues.

In the zero clastic supply scenario, as the rate of accommodation creation falls $(\mathrm{AR} / \mathrm{PPR}<1)$, peat will continue to accumulate at a decreasing rate, until the accommodation rate falls to zero. If the water table falls below the peat surface (AR/ PPR $<0$ ), degradation of peat above the water table will result in deflation and/or erosion of the mire surface. This results in an 'exposure' hiatus (Fig. 4b), which is characterized by a sharp, planar or erosive surface overlying a layer of degraded, oxidized 
A)

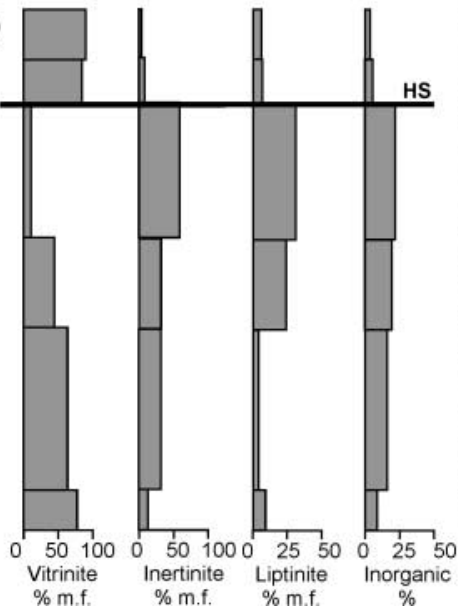

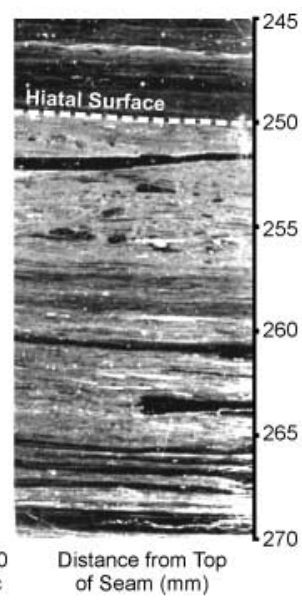

B)

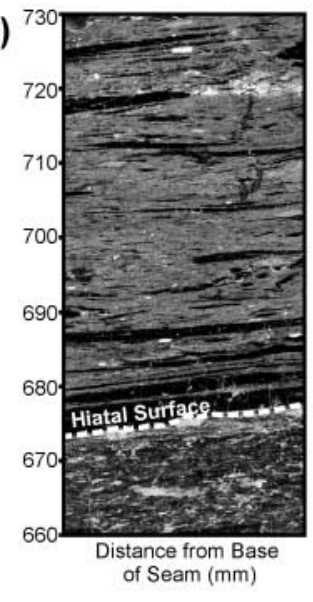

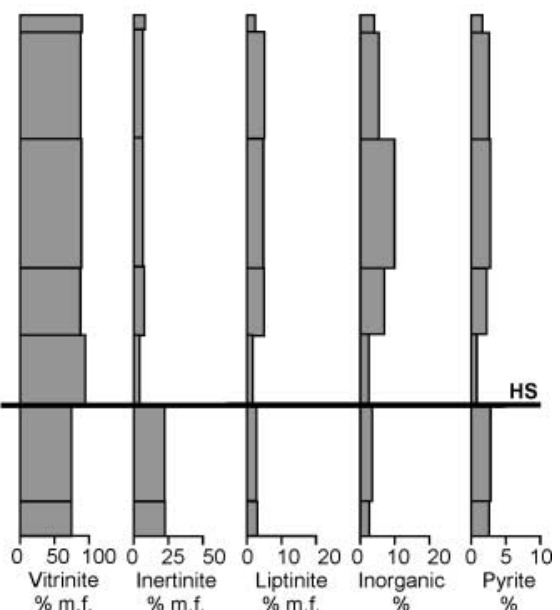

Fig. 3. Petrographic and macroscopic expression of hiatal surfaces in (a) the Fire Clay Coal and (b) the Sunnyside Coal. m.f., mineral free.
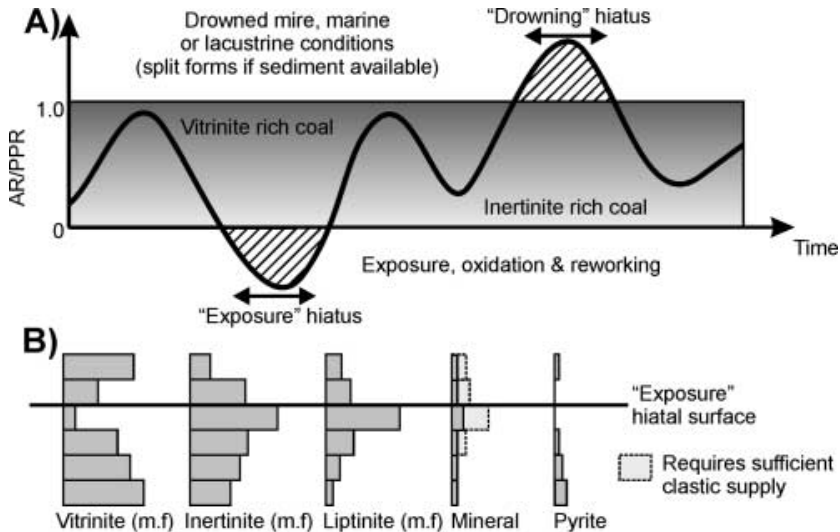

C)

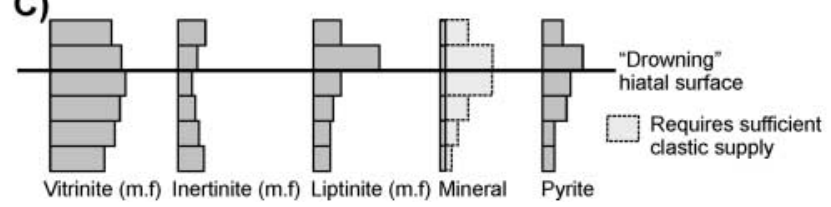

Fig. 4. (a) Modified version of the Wadsworth et al. (2002) model for settings without clastic sediment supply. As the accommodation rate (AR) falls, peat continues to accumulate until the AR reaches zero, resulting in the formation of a 'exposure' hiatal surface. In the absence of clastic sediment input, peat accumulation ceases when the long-term AR exceeds the rate of peat production, resulting in flooding of the mire and formation of a 'drowning' hiatal surface. (b) Generalized petrographic expression of 'exposure' hiatal surface. (c) Generalized petrographic expression of 'drowning' hiatal surface. m.f., mineral free.

and resistant macerals such as inertinite, liptinite and inorganic matter. This surface is analogous to a deflation or karst surface, which forms during base-level fall in an aeolian or carbonate environment, respectively. A subsequent increase in the accommodation rate $(A R / P P R>0)$ is required for the re-initiation of peat accumulation above the hiatal surface.

If the long-term accommodation rate exceeds the peat production rate $(\mathrm{AR} / \mathrm{PPR}>1)$, peat accumulation will cease as the mire is drowned and replaced by marine or lacustrine conditions. In the absence of clastic sedimentation, this results in a 'drowning' hiatus (Fig. 4c), which is likely to have a more subtle expression as a planar surface characterized by degraded, humified and resistant macerals such as unstructured vitrinite and liptinite (Fig. 4c). These represent a residue left over from biodegradation of the peat surface in subaqueous conditions. The settling from suspension of floating plant material that is resistant to degradation may also cause the hiatal surface to be overlain by a liptinite-enriched horizon (gyttja or sapropel), in contrast to an 'exposure' hiatal surface. This surface is analogous to a 'giveup' surface or hardground in carbonate environments, which forms when accommodation outpaces organic productivity. A decrease in the accommodation rate is required for the reinitiation of peat accumulation above the 'drowning' hiatal surface (Fig. 4a).

The case studies documented herein all represent 'exposure' hiatuses caused by a decrease in the rate of accommodation generation. 'Drowning' hiatuses associated with increased accommodation generation are less obviously documented in the literature. This is probably due to their subtle petrographic expression (Fig. 4c), and the fact that in most depositional systems flooding will be associated with an influx of clastic sediment (as currents provide a medium for the transport of allochthonous material), resulting in the formation of a clastic parting (Fig. 1) instead of a 'drowning' hiatal surface.

'Exposure' and 'drowning' hiatal surfaces represent the 'oxidized organic parting' and 'organic, non-oxidized degradative parting' of Shearer et al. (1994), who suggested that many coals may represent a succession of stacked mires separated by discontinuity surfaces that represent cessation of peat accumulation, hiatus and the initiation of a new mire. Shearer et al. (1994) also suggested that recognition of hiatal surfaces in coals can reconcile the apparent discrepancy between thicknesses of modern peat, which rarely exceed $20 \mathrm{~m}$ (Bruenig 1990), and coals, which may be up to $180 \mathrm{~m}$ (e.g. Holdgate et al. 1995).

Implications. The recognition of hiatal surfaces in coal has significant scientific and economic implications. Modern peatlands are generally viewed as both sinks and sources of global carbon, which cyclically respond to allogenic (climate and/or sealevel) forcing processes (Page et al. 2004). Coals are now increasingly being used as high-resolution time series of (palaeo-) environmental and base-level change (e.g. Lücke et al. 1999; Diessel et al. 2000; Wadsworth et al. 2002; Large et al. 2003; Davies et al. 2006; Briggs et al. 2007; Holdgate et al. 2007) 
because there is a common misconception that the coals correspond to single palaeo-peat bodies that represent a continuous record of peat accumulation. Although coals may generally represent more continuous records than terrestrial clastic strata that are deposited in beds during discrete events (Davies et al. 2006), the case studies presented herein demonstrate that significant time gaps can occur in peat and coal records. Hence, tuning non-linear peat and coal records to calibrated time scales can yield misleading results (Holdgate et al. 2007).

Recognizing that many economically viable coals are composed of a succession of stacked palaeo-peat bodies with different areal distributions and overall compositions may also yield improvements in the predictability of whole-seam quality and composition; this is a factor that is becoming increasingly important with exploration for, and exploitation of coal bed methane.

\section{References}

Anshari, G., Kershaw, P.A. \& Van Der KaArs, S. 2001. A Late Pleistocene and Holocene pollen and charcoal record from peat swamp forest, Lake Sentarum Wildlife Reserve, West Kalimantan, Indonesia. Palaeogeography, Palaeoclimatology, Palaeoecology, 171, 213-228.

Bohacs, K. \& Suter, J. 1997. Sequence stratigraphic distribution of coaly rocks: fundamental controls and paralic examples. AAPG Bulletin, 81, 1612-1639.

Bоотн, R.K., Rich, F.J. \& Bishop, G.A. 1999. Palynology and depositional history of Late Pleistocene and Holocene coastal sediments from St. Catherines Island, Georgia, U.S.A. Palynology, 23, 67-86.

BriggS, J., LARGe, D.J., ET AL. 2007. Influence of climate and hydrology on carbon in an early Miocene peatland. Earth and Planetary Science Letters, 253, $445-454$.

Bruenig, E.F. 1990. Oligotrophic forested wetlands in Borneo. In: Lugo, A.E., Brinson, M. \& Brown, S. (eds) Ecosystems of the World 15: Forested Wetlands. Elsevier Science Publishers B.V., Amsterdam, 299-344.

Clymo, R.S. 1984. The limits to peat bog growth. Philosophical Transactions of the Royal Society of London, Series B, 303, 605-654.

Davies, R., Howell, J., Boyd, R., Flint, S. \& Diessel, C. 2006. High-resolution sequence-stratigraphic correlation between shallow-marine and terrestrial strata: Examples from the Sunnyside Member of the Cretaceous Blackhawk Formation, Book Cliffs, eastern Utah. AAPG Bulletin, 90, 1121-1140.

Diessel, C. 1992. Coal-bearing Depositional Systems. Springer, Berlin.

DiEssel, C. 1998. Sequence stratigraphy applied to coal seams: two case histories. In: Shanley, K.W. \& McCabe, P.J. (eds) Relative Role of Eustacy, Climate and Tectonism in Continental Rocks. Society of Economic Paleontologists and Mineralogists, Special Publications, 59, 151-173.

Diessel, C., Boyd, R., Wadsworth, J., Leckie, D. \& Chalmers, G. 2000. On balanced and unbalanced accommodation/peat accumulation ratios in the Cretaceous coals from Gates Formation, Western Canada, and their sequencestratigraphic significance. International Journal of Coal Geology, 43, 143-186.

Greb, S.F., Eble, C.F. \& Hower, J.C. 1999. Depositional history of the Fire Clay coal bed (Late Duckmantian), Eastern Kentucky, USA. International Journal of Coal Geology, 40, 255-280.

Greb, S.F., Eble, C.F., Hower, J.C. \& Andrews, W.M. 2002. Multiple-bench architecture and interpretations of original mire phases-Examples from the Middle Pennsylvanian of the Central Appalachian Basin, USA. International Journal of Coal Geology, 49, 147-175.

Holdgate, G.R., Kershaw, A.P. \& Sluiter, I.R.K. 1995. Sequence stratigraphic analysis and the origins of Tertiary brown coal lithotypes, Latrobe Valley, Gippsland Basin, Australia. International Journal of Coal Geology, 28, 249275 .

Holdgate, G.R., Cartwright, I., Blackburn, D.T., Wallace, M.W., GallaGher, S.J., Wagstaff, B.E. \& Chung, L. 2007. The Middle Miocene Yallourn coal seam-The last coal in Australia. International Journal of Coal Geology, 70, 95-115.

Holdgate, G.R., McGrowan, B., ET AL. 2009. Eocene-Miocene carbon-isotope and floral record from brown coal seams in the Gippsland Basin of southeast Australia. Global and Planetary Change, 65, 89-103.

InGRAM, H.A.P. 1978. Soil layers in mires-function and terminology. Journal of Soil Science, 29, 224-227.

Jerrett, R.M., Flint, S.S., Davies, R.C. \& Hodgson, D.M. 2011. Sequence stratigraphic interpretation of a Pennsylvanian (Upper Carboniferous) coal from the central Appalachian Basin, USA. Sedimentology, doi: 10.1111/ j.1365-3091.2010.01200.x.

Kershaw, A.P. 1995. Environmental change in Greater Australia. Antiquity, 69, $656-675$.

Large, D.J., Jones, T.F., Somerfield, C., Gorringe, M.C., Spiro, B., MacQuaKER, J.H.S. \& ATKIN, B.P. 2003. High-resolution terrestrial record of orbital climate forcing in coal. Geology, 31, 303-306.

Ledru, M.-P., Bertaux, J., Sifeddine, A. \& Suguio, K. 1998. Absence of Last Glacial Maximum records in lowland tropical forests. Quaternary Research, 49, 233-237.

Lindsay, G. \& Herbert, C. 2002. Coal and conglomerate in the Newcastle Coal Measures - coeval facies or temporally unrelated? International Journal of Coal Geology, 51, 169-184.

Lücke, A., Helle, G., Schleser, G.H., Figueiral, I., Mosbrugger, V., Jones, T.P. \& Rowe, N.P. 1999. Environmental history of the German Lower Rhine Embayment during the Middle Miocene as reflected by carbon isotopes in brown coal. Palaeogeography, Palaeoclimatology, Palaeoecology, 154, 339352.

Page, S.E., Wüst, R.A.J., Weiss, D., Rieley, J.O., Shotyk, W. \& Limin, S.H. 2004. A record of Late Pleistocene and Holocene carbon accumulation and climate change from an equatorial peat bog (Kalimantan, Indonesia): implications for past, present and future carbon dynamics. Journal of Quaternary Science, 19, 625-635.

Ryer, T.A. \& LANGer, A.W. 1980. Thickness change involved in the peat-to-coal transformation for a bituminous coal of Cretaceous age in central Utah. Journal of Sedimentary Research, 50, 987-992.

Shearer, J.C., Staub, J.R. \& Moore, T.A. 1994. The conundrum of coal bed thickness: A theory for stacked mire sequences. Journal of Geology, 102, $611-617$.

Staub, J.R. 1991. Comparisons of central Appalachian Carboniferous coal beds by benches and a raised Holocene peat deposit. International Journal of Coal Geology, 18, 45-69.

TAYLOR, D.R. \& Lovell, W.W. 1995. Recognition of high frequency sequences in the Kenilworth Member of the Blackhawk Formation, Book Cliffs, Utah. In: VAn Wagoner, J.C. \& Bertram, G.T. (eds) Sequence Stratigraphy of Foreland Basin Deposits: Outcrop and Subsurface Examples from the Cretaceous of North America. American Association of Petroleum Geologists, Memoirs, 64, 257-277.

Wadsworth, J., Boyd, R., Diessel, C., Leckie, D. \& Zaitlin, B.A. 2002. Stratigraphic style of coal and non-marine strata in a tectonically influenced intermediate accommodation setting: the Mannville Group of the Western Canadian Sedimentary Basin, south-central Alberta. Bulletin of Canadian Petroleum Geology, 50, 507-541.

Watts, W.A. 1971. Postglacial and interglacial vegetation history of southern Georgia and central Florida. Ecology, 52, 676-690.

Webв, R.S. \& Wевв, T. 1988. Rates of sediment accumulation in pollen cores from small lakes and mires of eastern North America. Quaternary Research, 30, $284-297$. 